\title{
Efficacy and safety of tocilizumab (TCZ) in patients with systemic juvenile idiopathic arthritis (SJIA): tender 52-week data
}

\author{
F De Benedetti ${ }^{*}$, H Brunner ${ }^{2}$, N Ruperto ${ }^{3}$, R Schneider ${ }^{2}$, P Woo ${ }^{3}$, R Burgos-Vargas $^{3}$, P Dolezalova ${ }^{3}$, R Joos $^{3}$,

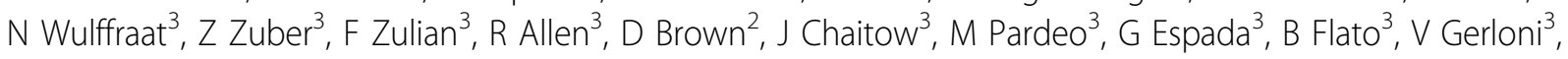 \\ G Horneff $^{3}$, S Wright $^{4}$, A Kenwright $^{4}$, D Lovell $^{2}$, A Martini $^{3}$
}

From 18th Pediatric Rheumatology European Society (PReS) Congress

Bruges, Belgium. 14-18 September 2011

\section{Background}

sIIA refractory to immunosuppressants including methotrexate and TNF- $\alpha$ inhibitors can lead to severe disabilities. Excessive IL-6 production has been implicated in the pathoetiology of sJIA.

\section{Aim}

To determine the efficacy and safety of TCZ, an IL-6 receptor inhibitor, in patients (pts) with sJIA treated for 52 weeks (wks) in the ongoing, 3-part, 5-year, phase 3 TENDER study.

\section{Methods}

Pts $(\mathrm{N}=112) 2-17$ years with active sJIA for $\geq 6$ months were randomized $2: 1$ to $\mathrm{TCZ}(8 \mathrm{mg} / \mathrm{kg}$ if body weight $\geq 30 \mathrm{~kg} ; 12 \mathrm{mg} / \mathrm{kg}$ if $<30 \mathrm{~kg}$ ) or placebo every $2 \mathrm{wks}$ for 12 wks in part 1; all pts received open-label (OL) TCZ in part 2. Pts who escaped to OL TCZ in part 1 also entered part 2. Oral corticosteroid (CS) tapering was permitted at wks 6 and 8 in part 1 and in the OL extension in the presence of ACR70 response, ESR $<20 \mathrm{~mm} /$ $h$, and absence of fever. Efficacy data included pts who reached wk 52 of TCZ treatment $(n=88)$; safety data considered all pts $(\mathrm{N}=112)$.

\section{Results}

Proportions of TCZ pts who achieved JIA ACR30 + absence of fever or JIA ACR70/90 increased to wk 52 (Table). Number of joints with active arthritis or with

* Correspondence: fabrizio.debenedetti@opbg.net

${ }^{1}$ Ospedale Bambino Gesù, Rome, Italy

Full list of author information is available at the end of the article limitation of movement decreased from $19.8 \pm 15.7$ and $19.8 \pm 15.6$, respectively, to $3.0 \pm 7.0$ and $7.5 \pm 11.7$ at wk 52 (45\% of pts had 0 active joints). CHAQ-DI score improved from $1.7 \pm 0.9$ to $0.7 \pm 0.8$ at wk 52 . Physician global assessment VAS and pt/parent global assessment VAS improved from $64.9 \pm 22.3$ and $58.7 \pm 24.4$, respectively, to $9.7 \pm 12.8$ and $12.6 \pm 18.5$ at wk 52 . CS dose decreased from $0.30 \pm 0.20 \mathrm{mg} / \mathrm{kg} / \mathrm{d}$ to $0.06 \pm 0.08$ at wk 52 ; $48 \%$ discontinued CSs. 33 serious AEs (SAEs) occurred in 25 pts; 12 SAEs were considered related (remotely, possibly, or probably) to TCZ (rate: $0.23 /$ pt year [PY] in part $1,0.25 /$ PY in part 2). 15 serious infections occurred; 6 (gastroenteritis, varicella, septic arthritis, otitis media, pharyngotonsillitis, upper respiratory tract infection) were considered related to TCZ; all resolved and none led to discontinuation. 12 pts withdrew (4, AEs; 4, insufficient response). One pt died of a suspected tension pneumothorax considered unrelated to treatment.

\section{Conclusions}

TENDER 1-year results demonstrate that TCZ is highly effective and generally well tolerated in pts with sJIA.

\begin{tabular}{llll}
\hline & Wk 12 & Wk 52 \\
\hline Responses & $\begin{array}{l}\text { Placebo } \\
(\mathbf{n = 3 7 )}\end{array}$ & $\begin{array}{l}\text { TCZ } \\
(\mathbf{n}=\mathbf{7 5})\end{array}$ & $\begin{array}{l}\text { TCZ } \\
(\mathbf{n}=\mathbf{8 8})\end{array}$ \\
\hline JIA ACR30 + absence of fever, & $9(24)$ & $64(85)$ & $77(88)$ \\
n (\%) & & & \\
JA ACR70, n (\%) & $3(8)$ & $53(71)$ & $78(89)$ \\
JA ACR90, n (\%) & $2(5)$ & $28(37)$ & $57(65)$ \\
\hline
\end{tabular}

\section{() Biomed Central}

(c) 2011 De Benedetti et al; licensee BioMed Central Ltd. This is an open access article distributed under the terms of the Creative Commons Attribution License (http://creativecommons.org/licenses/by/2.0), which permits unrestricted use, distribution, and reproduction in any medium, provided the original work is properly cited. 


\section{Author details}

'Ospedale Bambino Gesù, Rome, Italy. ${ }^{2}$ PRCSG, Cincinnati, USA. ${ }^{3}$ PRINTO,

Genoa, Italy. ${ }^{4}$ Roche, Welwyn, UK.

Published: 14 September 2011

doi:10.1186/1546-0096-9-S1-P164

Cite this article as: De Benedetti et al:: Efficacy and safety of tocilizumab (TCZ) in patients with systemic juvenile idiopathic arthritis (SJIA): tender 52-week data. Pediatric Rheumatology 2011 9(Suppl 1):P164.

Submit your next manuscript to BioMed Central and take full advantage of:

- Convenient online submission

- Thorough peer review

- No space constraints or color figure charges

- Immediate publication on acceptance

- Inclusion in PubMed, CAS, Scopus and Google Scholar

- Research which is freely available for redistribution

Submit your manuscript at www.biomedcentral.com/submit
C Biomed Central 